\title{
Growth Charts for Croatian School Children and Secular Trends in Past Twenty Years
}

\author{
Vesna Jureša ${ }^{1}$, Vera Musil ${ }^{1}$ and Mirjana Kujundžić Tiljak $^{2}$ \\ ${ }^{1}$ University of Zagreb, School of Medicine, »Andrija Štampar« School of Public Health, Department of Social Medicine and \\ Organization of Health Care, Zagreb, Croatia \\ 2 University of Zagreb, School of Medicine, »Andrija Štampar« School of Public Health, Department of Medical Statistics, \\ Epidemiology and Medical Informatics, Zagreb, Croatia
}

\begin{abstract}
A B S T R A C T
The aim of this study was to construct new Croatian growth charts for body height and weight of boys and girls aged 6.5 to 18.5 years and to investigate differences between our and pre-existing studies. Analysis was based on a multistage stratified sample representative for school children aged 6.5 to 18.5, 6046 boys and 5656 girls. Growth reference was constructed using LMS method. Present results demonstrated an increment of body height and weight during the last two decades. Highest increase of body height is in boys aged 13-14 years $6.5 \mathrm{~cm}$, in girls aged 12 years is $5.0 \mathrm{~cm}$. Highest increase of body weight is in 16 year age group of boys $8.7 \mathrm{~kg}$ and in 11-12 year age group of girls $5.2 \mathrm{~kg}$. In conclusion, regarding presence of secular trend because previously used growth charts in Croatia are obsolete.
\end{abstract}

Key words: growth charts, trends, children, adolescents, Croatia

\section{Introduction}

Need for development of growth charts and prospective studies of growth changes are today still actual and important. Growth charts are used in assessments of growth of healthy children and in detecting children with growth disturbances and different diseases which influenced $\mathrm{it}^{1}$. Secular growth trend presence $\mathrm{e}^{2-12}$ causes need for periodic studies and/or continuous follow ups. In Croatia last comprehensive measurement was taken in 1980-1984 ${ }^{13}$ and growth charts for school children aged 6 to 19 were made. Assessment of growth based on that data became insufficiently precise for today's children and there was need for developing new growth charts and national reference values.

The aim of this study was to construct new growth charts with Croatian national reference values for body height and weight of boys and girls aged 6.5 to 18.5 years and to investigate differences between our and 19801984 Prebeg's study ${ }^{13}$ with assessment of secular growth trend existence.

\section{Sample and Methods}

The paper analyzes the data collected in the Cardiovascular risk factors in school age-intervention model de- velopment project of the Ministry of Science, Education and Sport Republic of Croatia, No. 108-1080135-0263, conducted November 2006-January 2008 on the stratified random sample of Croatian school children aged $6.5-18.5$ years.

Answers and measurements were obtained for 11702 subjects (6046 boys and 5656 girls). Response was $94.5 \%$. Methodology for sampling was developed during project School Health Survey (part of 2003 Croatian Adult Health Survey conducted in collaboration of Croatian Ministry of Health and Social Welfare and Canadian Society for International Health and supported by Ministry of Science, Education and Sport ${ }^{14}$. Data about number of schools, classes and children attending all primary and secondary schools in Croatia were gathered from Croatian Ministry of Education. This survey targeted school children at primary school grades I to VIII aged 7 (6.507.49) and aged 14 (13.50-14.49) years, and at secondary school aged 15 to 18.5 (14.50-18.50) living in Croatia. This survey component covers $94.5 \%$ of the targeted age groups. To meet the survey objectives of providing reliable estimates at Croatia level a sample of 1000 respondents at each age was selected. The sample of individuals was selected using a three-staged cluster sample design

Received for publication September 1, 2011 
where primary schools and secondary school were the primary sampling units and classrooms the secondary sampling units. In order to ensure high efficiency of the sample design, the primary schools were systematically selected with a probability proportional to the total number of students in primary schools and in secondary schools. At the second stage of selection, one classroom of each grade at primary schools and two at secondary schools were randomly selected using a simple random sampling approach. At the third and last stage of selection, a $100 \%$ sample of individuals was selected in each selected classroom (all students were part of the sample). A complete list of in-scope primary and secondary schools was used as the sample frame for the first stage of selection. An in-scope primary and secondary school is defined as being a school where there is at least one classroom of either grade I to VIII in primary schools and I to III/IV in secondary schools regarding type of school. Of that list, some primary schools were however excluded for various reasons. The exclusions are the schools with less than 51 students and the special schools. Of that list, some secondary schools were excluded: two-year secondary schools, schools lacking $3^{\text {rd }}$ grade, some art schools and schools with less than 60 students. It is assumed that the excluded primary and secondary schools account for less than $5 \%$ of the students. At first stage, a sample of 40 primary schools was selected. In order to ensure a good representativity the sample of primary schools was stratified by settlements population size in five strata: 1 = Zagreb, Rijeka, Osijek, Split and settlements bigger than 200,001 inhabitants, $2=10,001$ to 200,000 inhabitants, $3=5,001$ to 10,000 inhabitants, $4=2,001$ to 5,000 inhabitants, $5=$ less then 2,000 inhabitants. At first stage, a sample of 20 secondary schools was selected. In order to ensure a good representativity the sample of secondary schools was stratified by type of school in three strata: 1 . grammar schools, 2. four-year schools, 3. three-year schools.

Number of primary schools by size of settlement: $1=$ 10 schools, $2=10$ schools, $3=4$ schools, $4=6$ schools, 5 $=10$ schools. Number of secondary schools by type of school: $1=6$ schools, $2=9$ schools, $3=5$ schools $^{15}$. In total 12389 individuals were selected to participate in the 2006-2008 survey. Out of these selected individuals a response was obtained for 11702 individuals which results in an overall response rate of $94.5 \%$. The following equation was used to compute response rates:

Response rate $=\frac{\text { number of responding individuals }}{\text { all in } \text { - } \text { scope individuals }}$

The survey response rate is obtained as follows:

$$
\text { Response rate }=\frac{11702}{12389}=0.9445
$$

The response rates per grade are as follows:

$$
\begin{aligned}
& \text { Primary shools : } \frac{7899}{8307}=0.9509 \\
& \text { Secondary shools : } \frac{3803}{4082}=0.9317
\end{aligned}
$$

\section{Ethical consideration}

After obtaining ethical permission by ethical comettte of University of Zagreb School of Medicine, schools were informed in advance by letter that the survey would be performed and provided with description of the research, via schools children and parents were informed. Because of the non-invasive nature of the protocol consisting only of a short questionnaire and measurements considered routine for school-entry/sports-participation and regular systematic examinations (i.e. height, weight, and blood pressure), a "passive consent « process was used. Parents/guardians and children were provided with a form on the first page of questionnaire that was to be returned if parents/guardians did not wish their child (or children personally) did not wish to participate.

Survey questionnaire consisted of following groups of questions and answers: A. Socio economic, demographic and family characteristics - Completed school of father and mother (incomplete primary school, primary school, three - year secondary school, four - year secondary school, college, university, unknown, not stated); Father and mother -working position (employed, unemployed, student, retired, desist, not stated) Occupation of father and mother (manager and politician, professional and scientists, engineer and technician, clerk or official and employee, service and commercial trade, farmer or forest worker or fisherman, craftsman and manufacture, heavy equipment operators and drivers, simple occupation, military service, unknown, not stated); Number of children in the family; Order of birth (firstborn, second born, third born, fourth born and more, not stated); B. Socio economic, demographic characteristics of selected respondent - Elementary School /Secondary school (code, grammar, three year secondary school, four year secondary school); Grade (1st grade, 2nd grade, .....); Class (a, $\mathrm{b}, \mathrm{c}, \ldots . .$. ); Gender (male, female); Date of birth (day, month, year); Where was child born? and Where does child live now? (same answer for every question): $1=$ Zagreb. Rijeka. Osijek. Split and settlements with more than 200,001 inhabitants, 2 = from 10,001 to $200,000,3$ $=$ from 5,001 to $10,000,4=$ from 2,001 to $5,000,5=$ less then 2,000 inhabitants; Scholastic ability last year (correct average). Anthropometric measurements body height, body weight, blood pressure, heart rate, waist and hips circumferences. Procedure lasted approximately 7-10 minutes per one student, and was executed by team of examiners - medical doctors.

Children were measured wearing light clothes and no shoes in calm, quite and comfortable setting. Body weight was measured on calibrated digital scale (Seca 862) and recorded to the nearest 100 grams and body height was measured with head positioned in Frankfurt plane by a fixed wall-mounted stadiometer and recorded to nearest 0.1 centimeters. Waist and hips circumferences were measured using non-elastic tape with the subject in standing position. Waist circumference was positioned in the line of belly button. At $10 \%$ of subjects measurement of body height, body weight, waist and hips circumferences was repeated for control use. Blood pressure mea- 
surements were taken during one visit to the schools. Blood pressure was measured after the child rested 10 minutes in a comfortable sitting position. None of the children were agitated and none of them had pain. Blood pressure was measured twice by auscultation using a standard sphygmomanometer (Riester) with a time interval of at least $30 \mathrm{sec}$ between the two measurements, on the right upper arm, bent 90 degrees at the elbow, with appropriate cuffs size and recorded to nearest 2 millimeters Hg. Phase I Korotkoff sound was used to indicate systolic blood pressure and phase $\mathrm{V}$ for diastolic blood pressure. Between two measures, the heart rate was measured in 30 seconds. Girls were directly asked whether they started to menstruate, and if yes, the exact month and year were recorded.

Data for this study were obtained from completion of questionnaire and physical examination. On the basis of the data obtained by measurements, body mass index (BMI) as weight/height ${ }^{2}$ (kilograms/square meter). Descriptive statistics was used to describe the distributions of height and weight. $3^{\text {rd }}, 10^{\text {th }}, 25^{\text {th }}, 50^{\text {th }}, 75^{\text {th }}, 90^{\text {th }}$ and $97^{\text {th }}$ percentiles, as well as the mean and standard deviation, and coefficient of variation were calculated. The sample of school children was weighted according to the census data. The difference between two measures (now and before 22 years) was calculated and graphically presented.

The Statistica 9.0 was used for data analysis. Body weight and body height percentile curves were constructed separately for boys and girls using LMS method ${ }^{16-18}$. Obtained curves represent Croatian reference values for height $(\mathrm{cm})$ and weight $(\mathrm{kg})$ for boys and girls 6.5 to 18.5 years of age, $3^{\text {rd }}, 5^{\text {th }}, 10^{\text {th }}, 15^{\text {th }}, 25^{\text {th }}, 50^{\text {th }}, 75^{\text {th }}, 85^{\text {th }}, 90^{\text {th }}$, $95^{\text {th }}$ and $97^{\text {th }}$ percentiles were constructed.

\section{Results}

The paper analyzes the only data about body height and body weight collected in the Cardiovascular risk factors in school age - intervention model development, project of the Ministry of Science, Education and Sport republic of Croatia, No. 108-1080135-0263, conducted November 2006-January 2008 on the stratified random sample of Croatian school children aged 6.5-18.5 years.

Table 1 shows body height and weight values for boys and girls of the two cohorts Prebeg 1980-1984 and our study Jureša 2006-2008. Shown are number of participants by age groups $7 \pm(6.50-7.49)$ to $18 \pm(17.50-18.49)$, mean $(\overline{\mathrm{X}})$, standard deviation (SD), coefficient of variation (CV), $\Delta=$ difference between 1980-1984 and 2006-2008, and pondered number of children in cohort 2006-2008

Today's 7 years old boys are $2.7 \mathrm{~cm}$ and girls $2.5 \mathrm{~cm}$ taller than their peers in Prebeg's study 1980-1984. Mean height increase for boys is 2.7 to $6.5 \mathrm{~cm}$ for boys and 2.5 to $5.0 \mathrm{~cm}$ for girls. Highest differences in mean height are in 13 and 14 year old boys $(6.5 \mathrm{~cm})$ and in 12 year old girls $(5.0 \mathrm{~cm})$.
Average increase in body weight for boys is between $2.4 \mathrm{~kg}$ ( 7 years old) to $8.7 \mathrm{~kg}$ (16 years old). For girls it is between $2.1 \mathrm{~kg}$ ( 17 years old) to $5.2 \mathrm{~kg}$ (11 and 12 years old).

Highest differences in mean weight are in 16 year old boys $(8.7 \mathrm{~kg})$ and in 11 and 12 year old girls $(5.2 \mathrm{~kg})$.

Percentile values for body height in our study 20062008 show increase compared with Prebeg's study 19801984. Value of the third percentile for body height in our study match 10 percentile value in Prebeg's study. Tenth percentile match 25 percentile, 25 percentile match 50 percentile, 50 percentile match 75 percentile, 75 percentile match 90 percentile, 90 percentile match 97 percentile of Prebeg's study. 97 percentile in our study is moved towards higher values of body height. It must be emphasized that value of 97 percentile in Prebeg's study for 7 year old boys was $136.0 \mathrm{~cm}$ and now is $138.5 \mathrm{~cm}$, for 7 year old girls was $135.0 \mathrm{~cm}$ and now is $136.8 \mathrm{~cm}$, value of 97 percentile in 18 year old boys was $190.0 \mathrm{~cm}$ and now is $195.7 \mathrm{~cm}$, for girls was $176.0 \mathrm{~cm}$ and now is $177.8 \mathrm{~cm}$ (Fig. 1).

Percentile values for body weight in our study 20062008 show increase compared with Prebeg's study 19801984. Value of the third percentile in our study match 10 percentile value in Prebeg's study. Tenth percentile for body weight match 25 percentile, 25 percentile match 50 percentile, 50 percentile match 75 percentile, 75 percentile match 90 percentile, 90 percentile match 97 percentile of Prebeg's study. 97 percentile in our study is moved towards higher values of body weight. It must be emphasized that value of 97 percentile in Prebeg's study for 7 year old boys was $35 \mathrm{~kg}$ and now is $40.6 \mathrm{~kg}$, for 7 year old girls was 35.5 and now is $40.5 \mathrm{~kg}$, value of 97 percentile in 18 year old boys was $86.1 \mathrm{~kg}$ and now is $106.2 \mathrm{~kg}$ (Fig. 2).

In Table 2 are shown percentiles for body height and in Table 3 percentiles for body weight of boys and girls aged 6.5 to 18.5 years (age groups are divided in two months classes). In all age groups percentile values are higher for boys than girls. Fiftieth percentile for body height of 18 year old boys is $180.40 \mathrm{~cm}$ and for girls is $166.49 \mathrm{~cm}$. Fiftieth percentile for body weight of 18 year old boys is $73.56 \mathrm{~kg}$ and for girls is $58.55 \mathrm{~kg}$.

\section{Discussion and Conclusion}

Comparing values of body height and body weight gathered in our study with Prebeg study 1980-1984 ${ }^{13}$ showed existence of secular trend in Croatia. Mean values for age group 7-18 years of body height and body weight are increased in comparison with mean values achieved 22 years ago. Seven year old boys in our study are $2.7 \mathrm{~cm}$ and girls $2.5 \mathrm{~cm}$ taller than peers in earlier study. 18 years old boys are $2.9 \mathrm{~cm}$ and girls $1.8 \mathrm{~cm}$ taller. Highest increase of body height is in boys aged 13-14 years $6.5 \mathrm{~cm}$, in girls aged 12 years is $5.0 \mathrm{~cm}$. 7 year old boys in our study are $2.4 \mathrm{~kg}$ heavier and girls are $2.5 \mathrm{~kg}$ heavier than their peers in earlier study. 18 year old boys are $6.0 \mathrm{~kg}$ heavier and girls are $0.5 \mathrm{~kg}$ heavier. Highest 
TABLE 1

BODY HEIGHT AND BODY WEIGHT FOR THE TWO COHORTS - PREBEG 1980-1984 AND JUREŠA 2006-2008, STRATIFIED FOR BOYS AND GIRLS

\begin{tabular}{|c|c|c|c|c|c|c|c|c|c|c|c|}
\hline \multirow{2}{*}{$\begin{array}{l}\text { Age } \\
\text { (years) }\end{array}$} & \multicolumn{3}{|c|}{$\mathrm{N}$} & \multicolumn{3}{|c|}{$\overline{\mathrm{X}}$} & \multicolumn{2}{|c|}{$\mathrm{SD}$} & \multicolumn{3}{|c|}{$\mathrm{CV}$} \\
\hline & $\begin{array}{c}\text { Prebeg } \\
1980-1984\end{array}$ & $\begin{array}{c}\text { Jureša } \\
2006-2008\end{array}$ & & $\begin{array}{c}\text { Prebeg } \\
\text { 1980-1984 }\end{array}$ & $\begin{array}{c}\text { Jureša } \\
2006-2008\end{array}$ & $\Delta$ & $\begin{array}{c}\text { Prebeg } \\
1980-1984\end{array}$ & $\begin{array}{c}\text { Jureša } \\
2006-2008\end{array}$ & $\begin{array}{c}\text { Prebeg } \\
1980-1984\end{array}$ & $\begin{array}{c}\text { Jureša } \\
2006-2008\end{array}$ & $\Delta$ \\
\hline \multicolumn{12}{|c|}{ Height. Boys } \\
\hline $7 \pm$ & 2657 & 384 & (1085) & 124.8 & 127.5 & 2.7 & 5.7 & 5.5 & $4.6 \%$ & $4.3 \%$ & -0.3 \\
\hline $8 \pm$ & 3039 & 521 & (1372) & 129.6 & 132.6 & 3.0 & 6.1 & 5.7 & $4.7 \%$ & $4.3 \%$ & -0.4 \\
\hline $9 \pm$ & 3159 & 502 & $(1562)$ & 134.9 & 138.6 & 3.7 & 6.4 & 6.8 & $4.8 \%$ & $4.9 \%$ & 0.1 \\
\hline $10 \pm$ & 2873 & 500 & (1709) & 140.1 & 143.6 & 3.5 & 6.9 & 6.6 & $4.9 \%$ & $4.6 \%$ & -0.3 \\
\hline $11 \pm$ & 3252 & 496 & (1694) & 145.0 & 148.8 & 3.8 & 7.2 & 6.9 & $5.0 \%$ & $4.6 \%$ & -0.4 \\
\hline $12 \pm$ & 3241 & 512 & (1648) & 149.9 & 155.1 & 5.2 & 7.8 & 8.4 & $5.2 \%$ & $5.4 \%$ & 0.2 \\
\hline $13 \pm$ & 3384 & 501 & (1668) & 156.1 & 162.6 & 6.5 & 8.7 & 9.0 & $5.5 \%$ & $5.5 \%$ & 0.0 \\
\hline $14 \pm$ & 3179 & 527 & (1690) & 163.1 & 169.6 & 6.5 & 9.6 & 8.9 & $5.9 \%$ & $5.2 \%$ & -0.7 \\
\hline $15 \pm$ & 3378 & 571 & (1690) & 169.6 & 175.2 & 5.6 & 8.8 & 8.0 & $5.2 \%$ & $4.6 \%$ & -0.6 \\
\hline $16 \pm$ & 2606 & 577 & $(1751)$ & 174.0 & 178.2 & 4.2 & 7.8 & 7.3 & $4.5 \%$ & $4.1 \%$ & -0.4 \\
\hline $17 \pm$ & 2485 & 515 & (1585) & 176.7 & 179.5 & 2.8 & 7.1 & 7.4 & $4.0 \%$ & $4.1 \%$ & 0.1 \\
\hline $18 \pm$ & 1949 & 358 & $(955)$ & 177.6 & 180.5 & 2.9 & 6.6 & 6.8 & $3.7 \%$ & $3.7 \%$ & 0.0 \\
\hline \multicolumn{12}{|c|}{ Height. Girls } \\
\hline $7 \pm$ & 2607 & 357 & (1073) & 124.0 & 126.5 & 2.5 & 5.6 & 5.5 & $4.5 \%$ & $4.3 \%$ & -0.2 \\
\hline $8 \pm$ & 2883 & 483 & (1415) & 128.7 & 131.8 & 3.1 & 6.2 & 6.4 & $4.8 \%$ & $4.9 \%$ & 0.1 \\
\hline $9 \pm$ & 2981 & 498 & (1469) & 134.1 & 137.4 & 3.3 & 6.4 & 6.5 & $4.8 \%$ & $4.7 \%$ & -0.1 \\
\hline $10 \pm$ & 2768 & 487 & $(1511)$ & 139.5 & 143.7 & 4.2 & 7.1 & 7.5 & $5.1 \%$ & $5.2 \%$ & 0.1 \\
\hline $11 \pm$ & 3224 & 512 & (1673) & 145.8 & 150.5 & 4.7 & 7.7 & 8.0 & $5.3 \%$ & $5.3 \%$ & 0.0 \\
\hline $12 \pm$ & 3134 & 476 & (1646) & 152.0 & 157.0 & 5.0 & 7.8 & 7.5 & $5.1 \%$ & $4.8 \%$ & -0.3 \\
\hline $13 \pm$ & 3439 & 498 & (1664) & 157.4 & 161.4 & 4.0 & 7.2 & 7.3 & $4.6 \%$ & $4.5 \%$ & -0.1 \\
\hline $14 \pm$ & 3163 & 564 & (1834) & 160.6 & 164.5 & 3.9 & 6.6 & 6.6 & $4.1 \%$ & $4.0 \%$ & -0.1 \\
\hline $15 \pm$ & 3414 & 434 & (1262) & 162.7 & 165.4 & 2.7 & 6.2 & 6.3 & $3.8 \%$ & $3.8 \%$ & 0.0 \\
\hline $16 \pm$ & 2774 & 439 & (1253) & 163.9 & 166.1 & 2.2 & 6.1 & 6.5 & $3.7 \%$ & $3.9 \%$ & 0.2 \\
\hline $17 \pm$ & 2590 & 474 & (1162) & 164.0 & 166.5 & 2.5 & 6.0 & 6.5 & $3.7 \%$ & $3.9 \%$ & 0.2 \\
\hline $18 \pm$ & 2149 & 360 & $(804)$ & 164.5 & 166.3 & 1.8 & 6.0 & 6.1 & $3.7 \%$ & $3.7 \%$ & 0.0 \\
\hline \multicolumn{12}{|c|}{ Weight. Boys } \\
\hline $7 \pm$ & 2657 & 384 & (1085) & 24.9 & 27.3 & 2.4 & 4.34 & 5.5 & $17.4 \%$ & $20.0 \%$ & 2.6 \\
\hline $8 \pm$ & 3039 & 521 & (1372) & 27.4 & 30.8 & 3.4 & 4.73 & 6.9 & $17.3 \%$ & $22.4 \%$ & 5.1 \\
\hline $9 \pm$ & 3159 & 502 & (1562) & 30.3 & 35.4 & 5.0 & 5.49 & 9.1 & $18.1 \%$ & $25.6 \%$ & 7.5 \\
\hline $10 \pm$ & 2873 & 500 & (1709) & 33.6 & 38.0 & 4.4 & 6.49 & 9.1 & $19.3 \%$ & $23.9 \%$ & 4.6 \\
\hline $11 \pm$ & 3252 & 496 & (1694) & 37.1 & 42.2 & 5.1 & 7.32 & 11.0 & $19.7 \%$ & $26.0 \%$ & 6.3 \\
\hline $12 \pm$ & 3241 & 512 & (1648) & 40.8 & 47.2 & 6.4 & 8.27 & 11.8 & $20.3 \%$ & $25.0 \%$ & 4.7 \\
\hline $13 \pm$ & 3384 & 501 & (1668) & 45.6 & 52.7 & 7.1 & 9.35 & 12.7 & $20.5 \%$ & $24.0 \%$ & 3.5 \\
\hline $14 \pm$ & 3179 & 527 & (1690) & 51.5 & 59.5 & 8.0 & 10.75 & 12.9 & $20.9 \%$ & $21.7 \%$ & 0.6 \\
\hline $15 \pm$ & 3378 & 571 & (1690) & 57.7 & 66.0 & 8.2 & 10.41 & 13.7 & $18.0 \%$ & $20.8 \%$ & 2.8 \\
\hline $16 \pm$ & 2606 & 577 & (1751) & 62.7 & 71.5 & 8.7 & 9.81 & 14.1 & $15.6 \%$ & $19.8 \%$ & 3.2 \\
\hline $17 \pm$ & 2485 & 515 & (1585) & 66.8 & 73.7 & 6.9 & 9.16 & 12.3 & $13.7 \%$ & $16.8 \%$ & 3.1 \\
\hline $18 \pm$ & 1949 & 358 & $(955)$ & 68.8 & 74.8 & 6.0 & 8.46 & 12.6 & $12.3 \%$ & $16.9 \%$ & 4.6 \\
\hline \multicolumn{12}{|c|}{ Weight. Girls } \\
\hline $7 \pm$ & 2607 & 357 & (1073) & 24.3 & 26.8 & 2.5 & 4.43 & 5.6 & $18.2 \%$ & $21.0 \%$ & 2.8 \\
\hline $8 \pm$ & 2883 & 483 & (1415) & 26.8 & 29.9 & 3.1 & 5.00 & 7.0 & $18.7 \%$ & $23.4 \%$ & 4.7 \\
\hline $9 \pm$ & 2981 & 498 & (1469) & 29.9 & 33.4 & 3.5 & 5.81 & 7.7 & $19.4 \%$ & $22.9 \%$ & 3.5 \\
\hline $10 \pm$ & 2768 & 487 & (1511) & 33.1 & 38.0 & 4.9 & 6.72 & 9.7 & $20.3 \%$ & $25.6 \%$ & 5.3 \\
\hline $11 \pm$ & 3224 & 512 & (1673) & 37.6 & 42.8 & 5.2 & 7.96 & 10.9 & $21.2 \%$ & $25.5 \%$ & 4.3 \\
\hline $12 \pm$ & 3134 & 476 & (1646) & 42.3 & 47.5 & 5.2 & 8.83 & 10.5 & $20.9 \%$ & $22.0 \%$ & 1.1 \\
\hline $13 \pm$ & 3439 & 498 & (1664) & 47.7 & 52.4 & 4.7 & 8.77 & 11.9 & $18.4 \%$ & $22.6 \%$ & 4.2 \\
\hline $14 \pm$ & 3163 & 564 & (1834) & 51.6 & 56.0 & 4.4 & 8.60 & 10.9 & $16.7 \%$ & $19.5 \%$ & 2.8 \\
\hline $15 \pm$ & 3414 & 434 & (1262) & 55.5 & 58.2 & 2.7 & 8.28 & 9.2 & $14.9 \%$ & $15.8 \%$ & 0.9 \\
\hline $16 \pm$ & 2774 & 439 & (1253) & 56.8 & 59.2 & 2.4 & 7.89 & 9.8 & $13.9 \%$ & $16.6 \%$ & 2.7 \\
\hline $17 \pm$ & 2590 & 474 & (1162) & 57.7 & 59.9 & 2.1 & 7.54 & 9.3 & $13.1 \%$ & $15.5 \%$ & 2.4 \\
\hline $18 \pm$ & 2149 & 360 & $(804)$ & 58.5 & 59.0 & 0.5 & 7.38 & 8.2 & $12.6 \%$ & $14.0 \%$ & 1.4 \\
\hline
\end{tabular}

Mean $(\overline{\mathrm{X}})$, standard deviation (SD), coefficient of variation $(\mathrm{CV}), \Delta=$ difference between -1984 and 2006-2008.

Note: number in () pondered number of children in cohort 2006-2008 

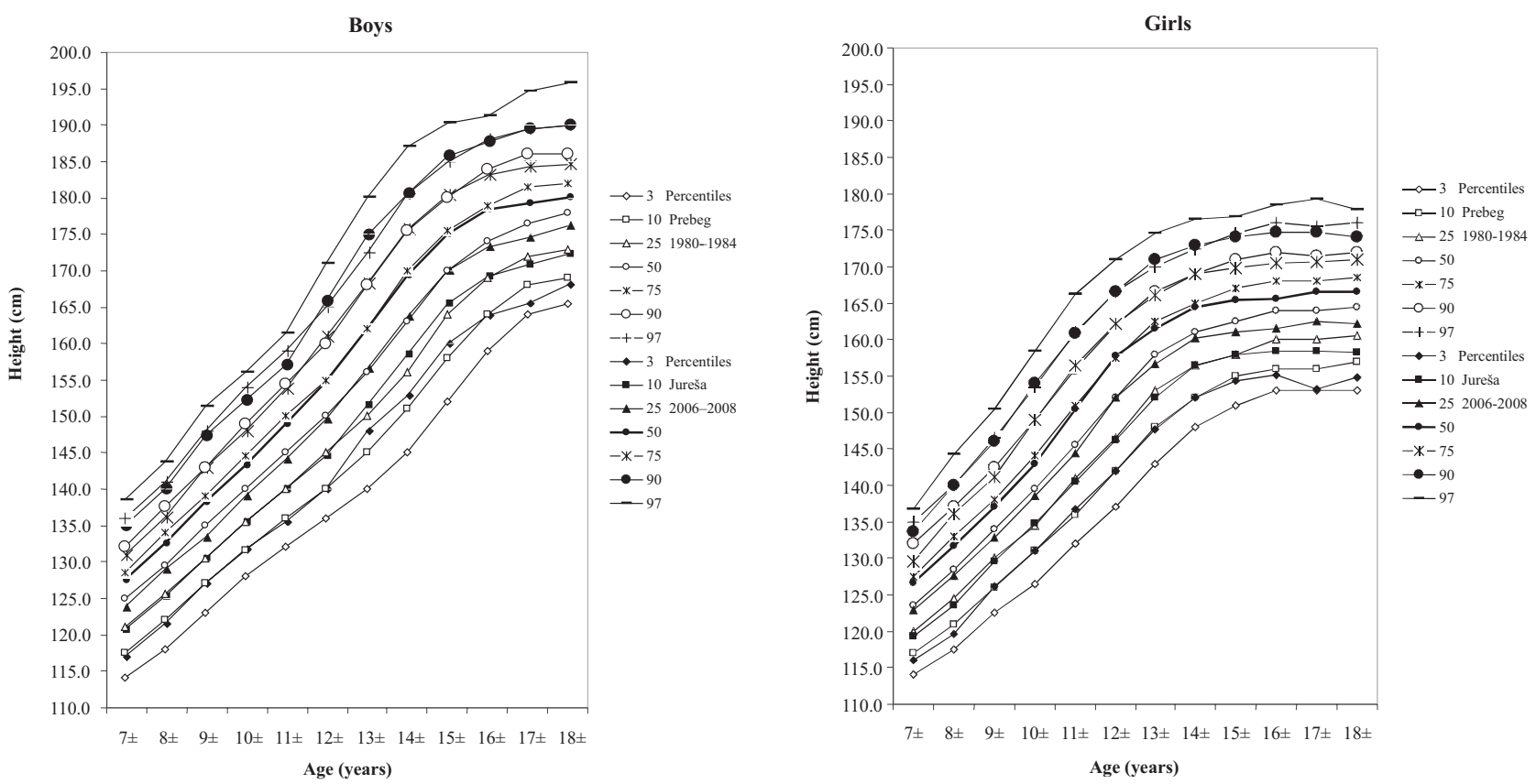

Fig. 1. Percentiles of height for the two cohorts - Prebeg 1980.- 1984 and Jureša 2006-2008. stratified for boys and girls.
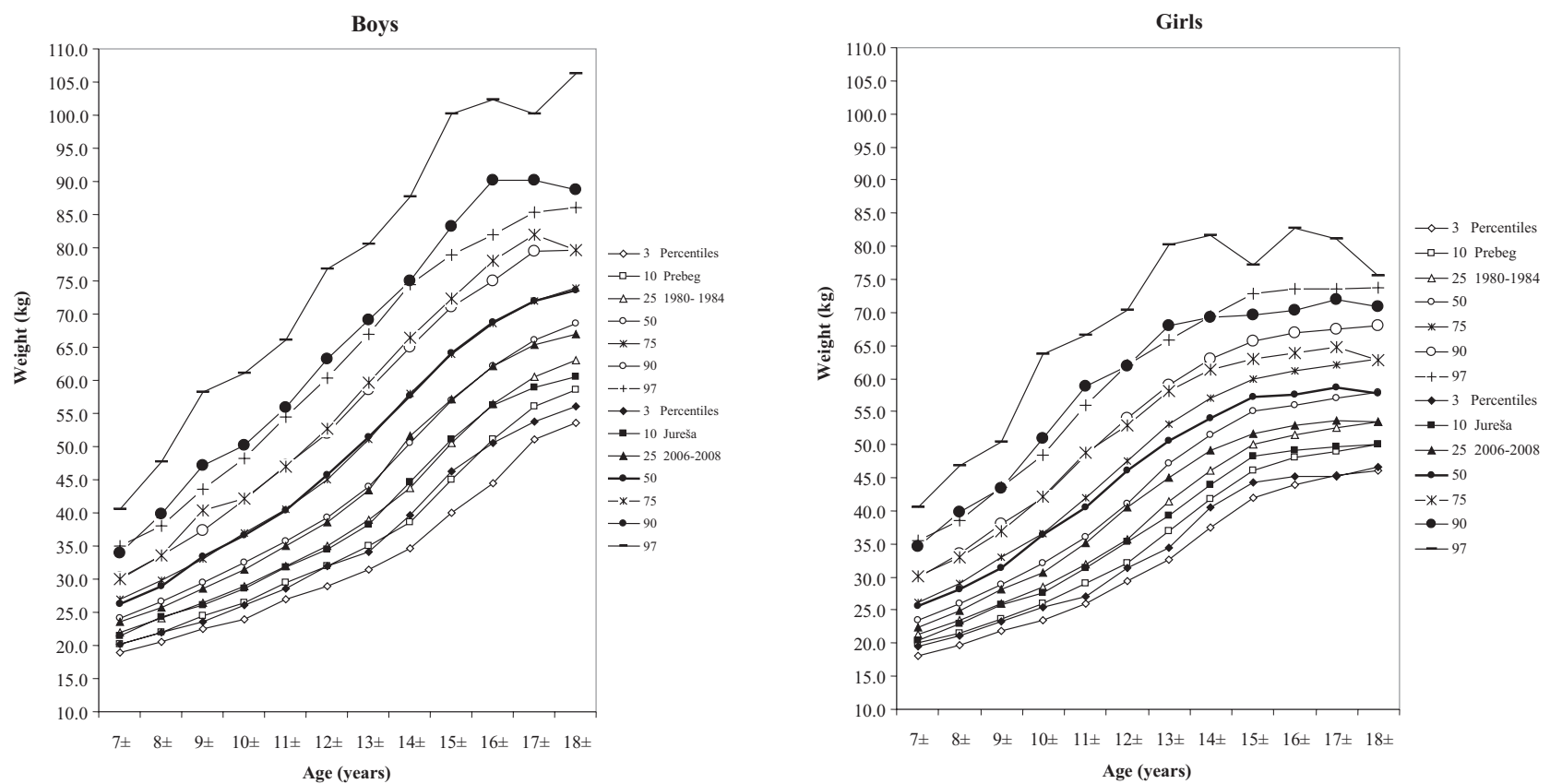

Fig. 2. Percentiles of weight for the two cohorts - Prebeg 1980-1984 and Jureša 2006-2008, stratified for boys and girls.

increase is in 16 year age group of boys $8.7 \mathrm{~kg}$ and in 11-12 year age group of girls $5.2 \mathrm{~kg}$. Comparison of percentile curves values for same age groups shows that ones achieved in our study are shifted to higher level. Fiftieth percentile of body height of 7 year old boys in Prebeg's study was $125.0 \mathrm{~cm}$ and $127.4 \mathrm{~cm}$ in our study, for girls it was $123.5 \mathrm{~cm}$ and now is $126.6 \mathrm{~cm}$. Fiftieth percentile for body weight of 7 year old boys in Prebeg's study was $24.1 \mathrm{~kg}$ and $26.3 \mathrm{~kg}$ in our study, for girls it was
$23.5 \mathrm{~kg}$ and now is $25.7 \mathrm{~kg}$. In one of the earlier Zagreb Croatia school children population study 1951-1991 the mean height of boys and girls in all observed groups has increased significantly over the 1951-1991 year period. In 19 year age group boys were $7 \mathrm{~cm}$ and girls were $5 \mathrm{~cm}$ taller $^{19}$. More recent studies 1991-2008 among 7 years old group of Croatian children showed significant increase of body height for boys $1.4 \mathrm{~cm}$ and girls $0.97 \mathrm{~cm}$. In 2008 girls are $1.5 \mathrm{~kg}$ heavier and boys are $1.4 \mathrm{~kg}$ heavier 
穴

8

$\infty$

记

政

เั่

诧

$\oplus$

运

$\stackrel{19}{\rightarrow}$

:

资

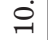

की

总

เ宀

ตั.

运

$\dot{\infty}$

客

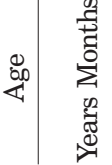

8

กิ

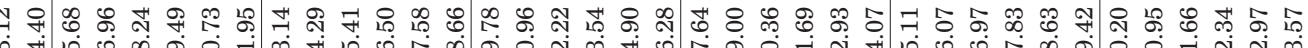

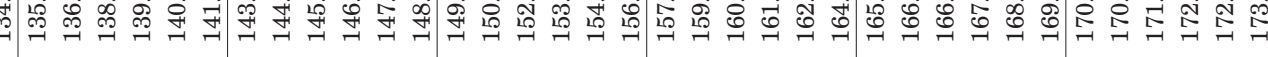

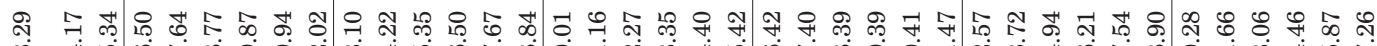

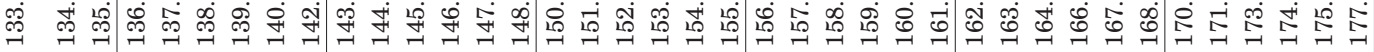

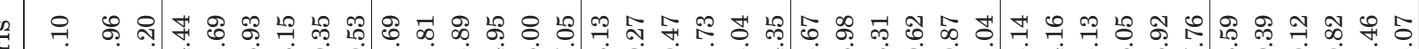

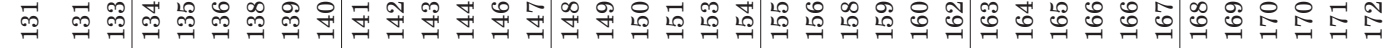
n $\infty \quad \& 7=0$

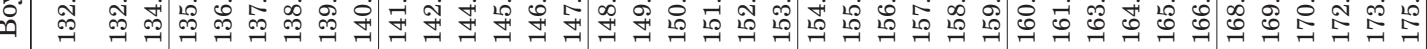
我

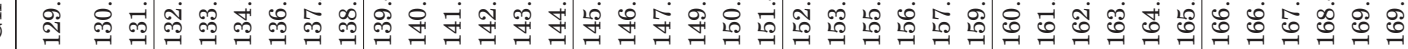

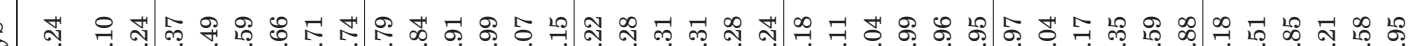

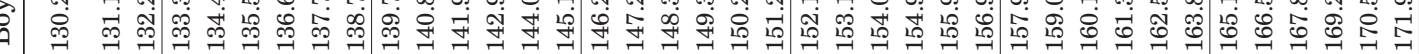

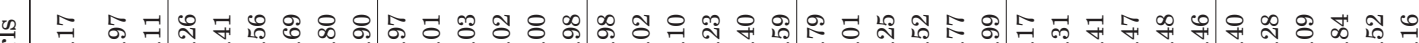

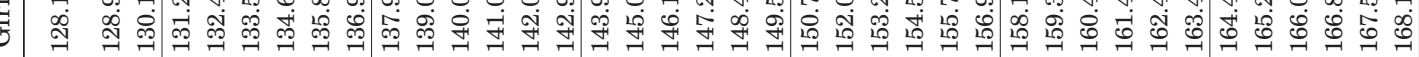

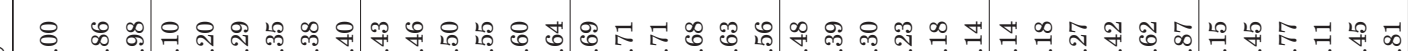

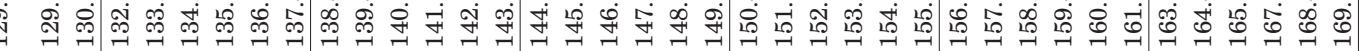

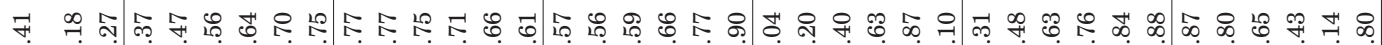

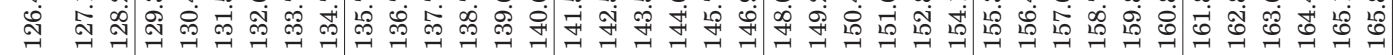

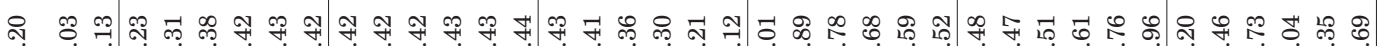

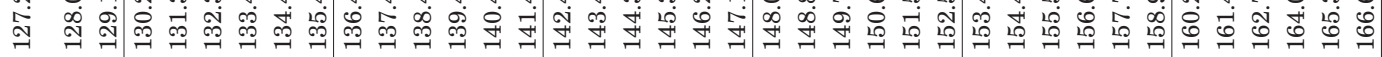

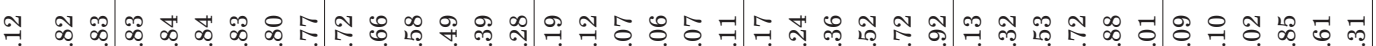

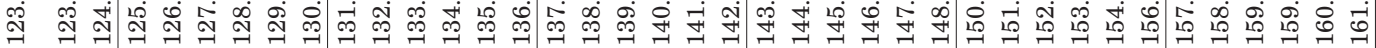

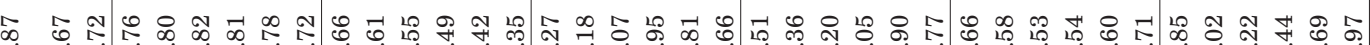

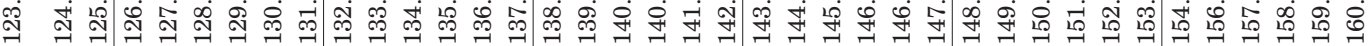

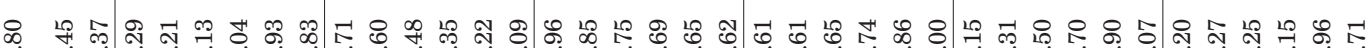

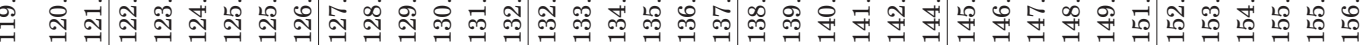

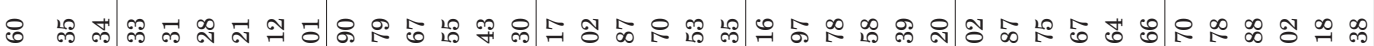

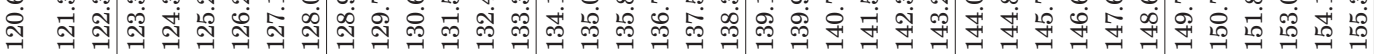

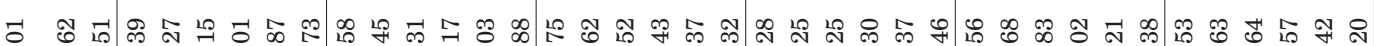

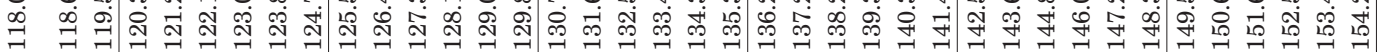
乍

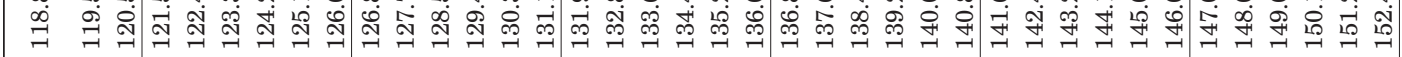

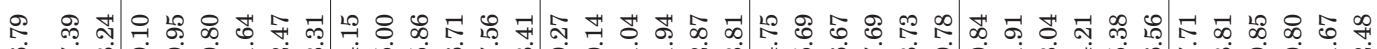

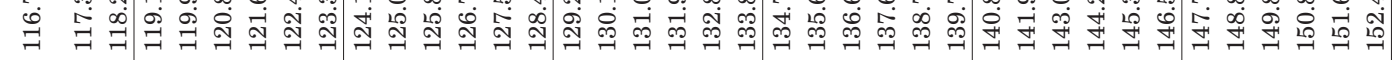

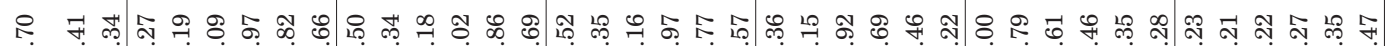

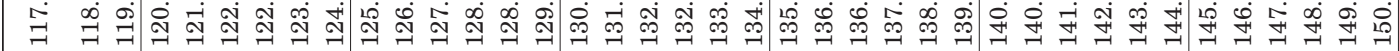

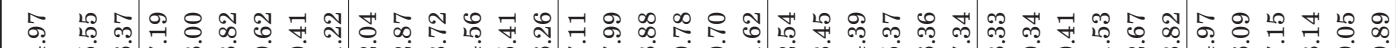

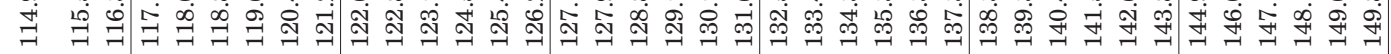

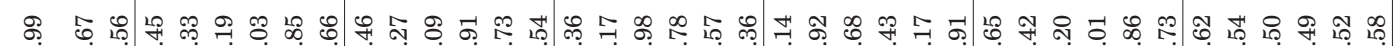

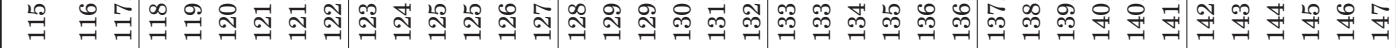

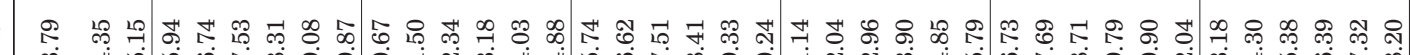

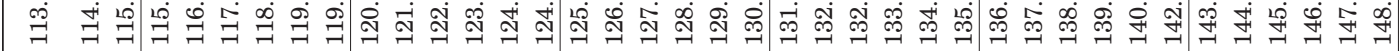

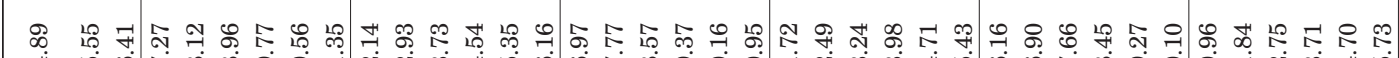

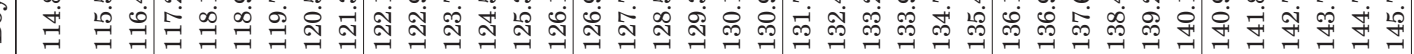
車

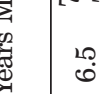

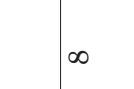

。

음 


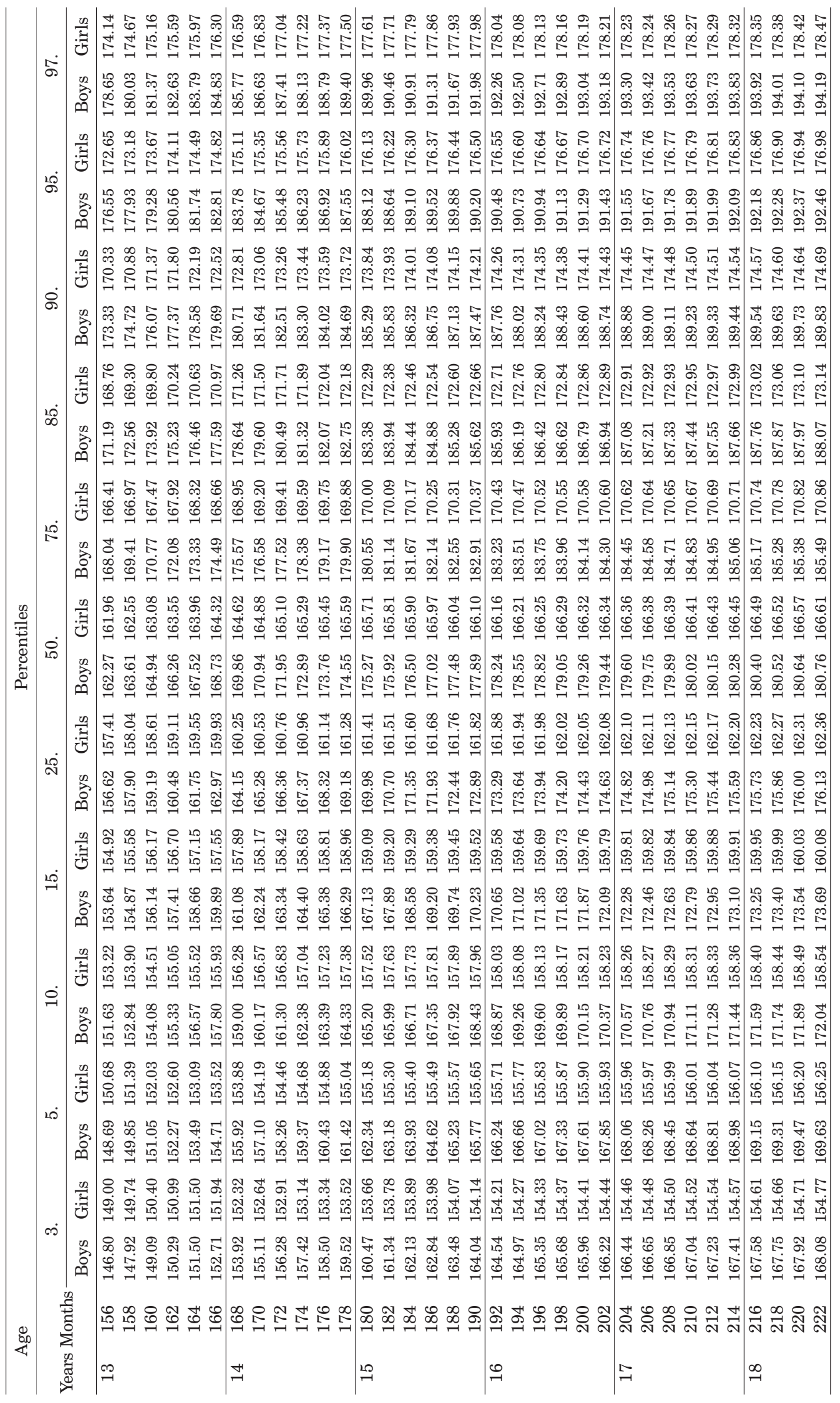


ธ่.

\&8

\&

$\infty$

용

욜

离

เล่

$\stackrel{10}{\rightarrow}$

$\therefore$

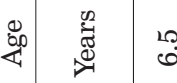

ن둥

.

คे

년

.

客

을

نे

望

$\infty$

년

(2)

๑

년

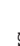

ตे

군

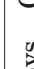

๑

논

.

๑

늘

둥

号

12

10

๑

ஜ

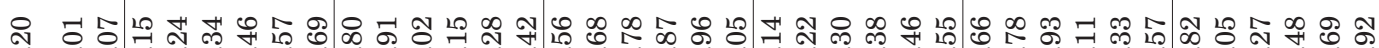

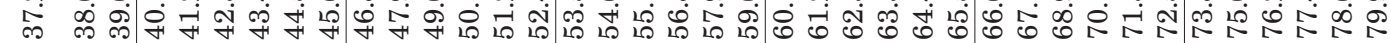

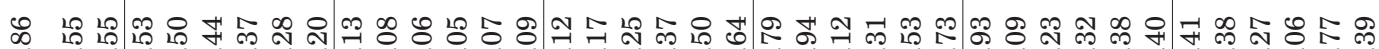

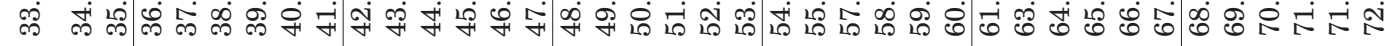

車

ஸ் 绝

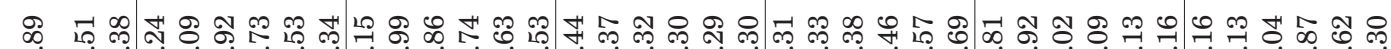

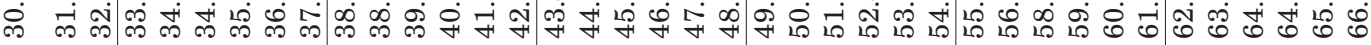

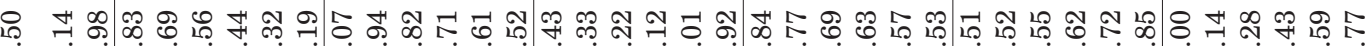

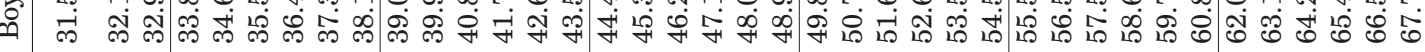

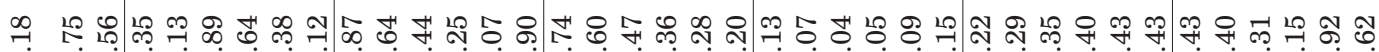

ริ

ㄱ.

过

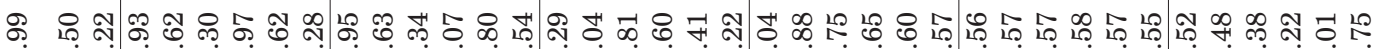

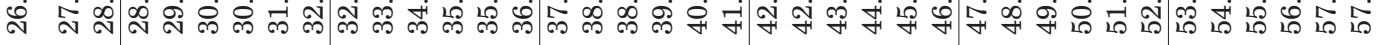

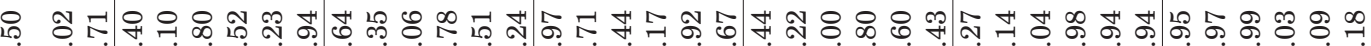

ล

넌

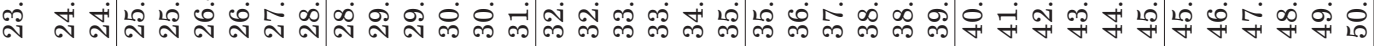

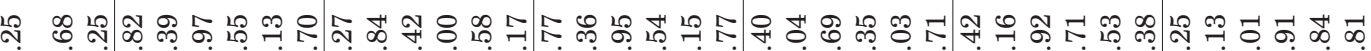

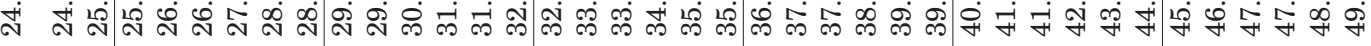

車

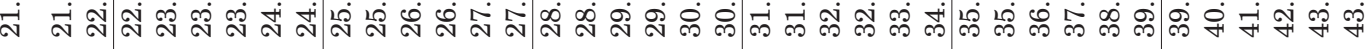

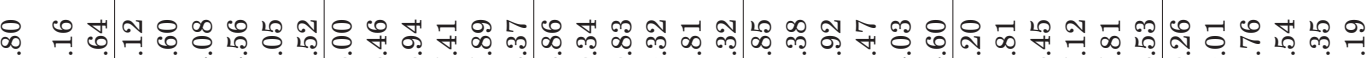

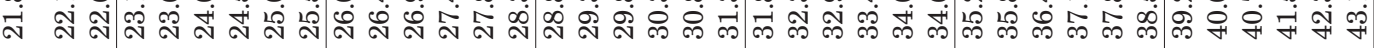

节 占

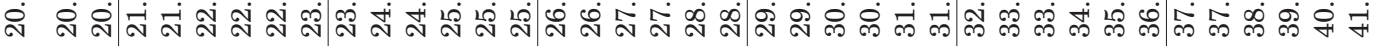

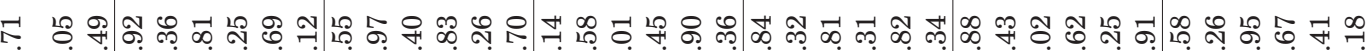

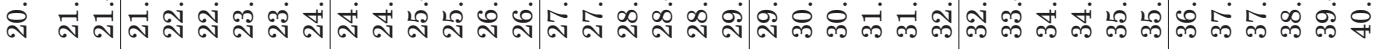

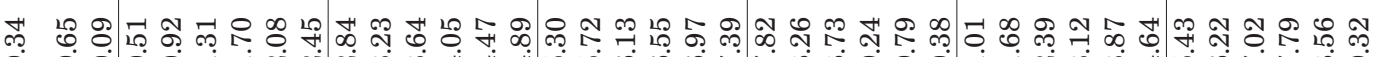

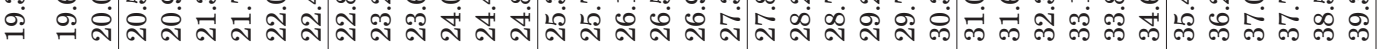

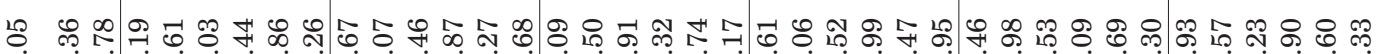

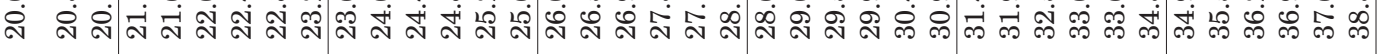

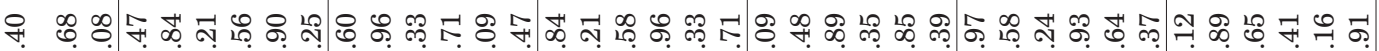

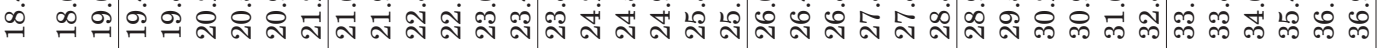

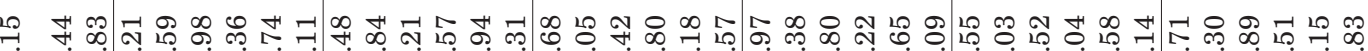

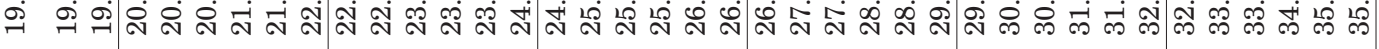

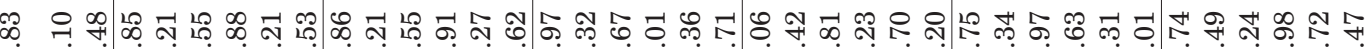

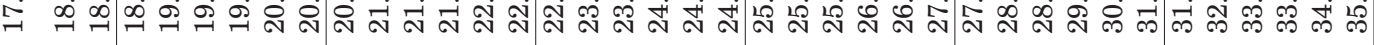

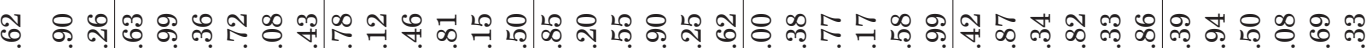

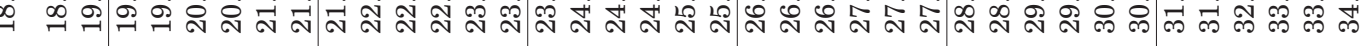

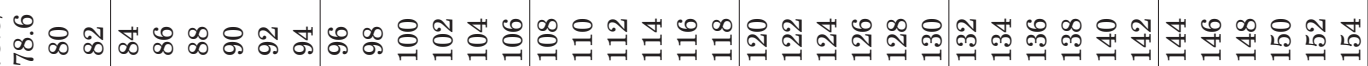

เ

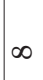

우

શ 


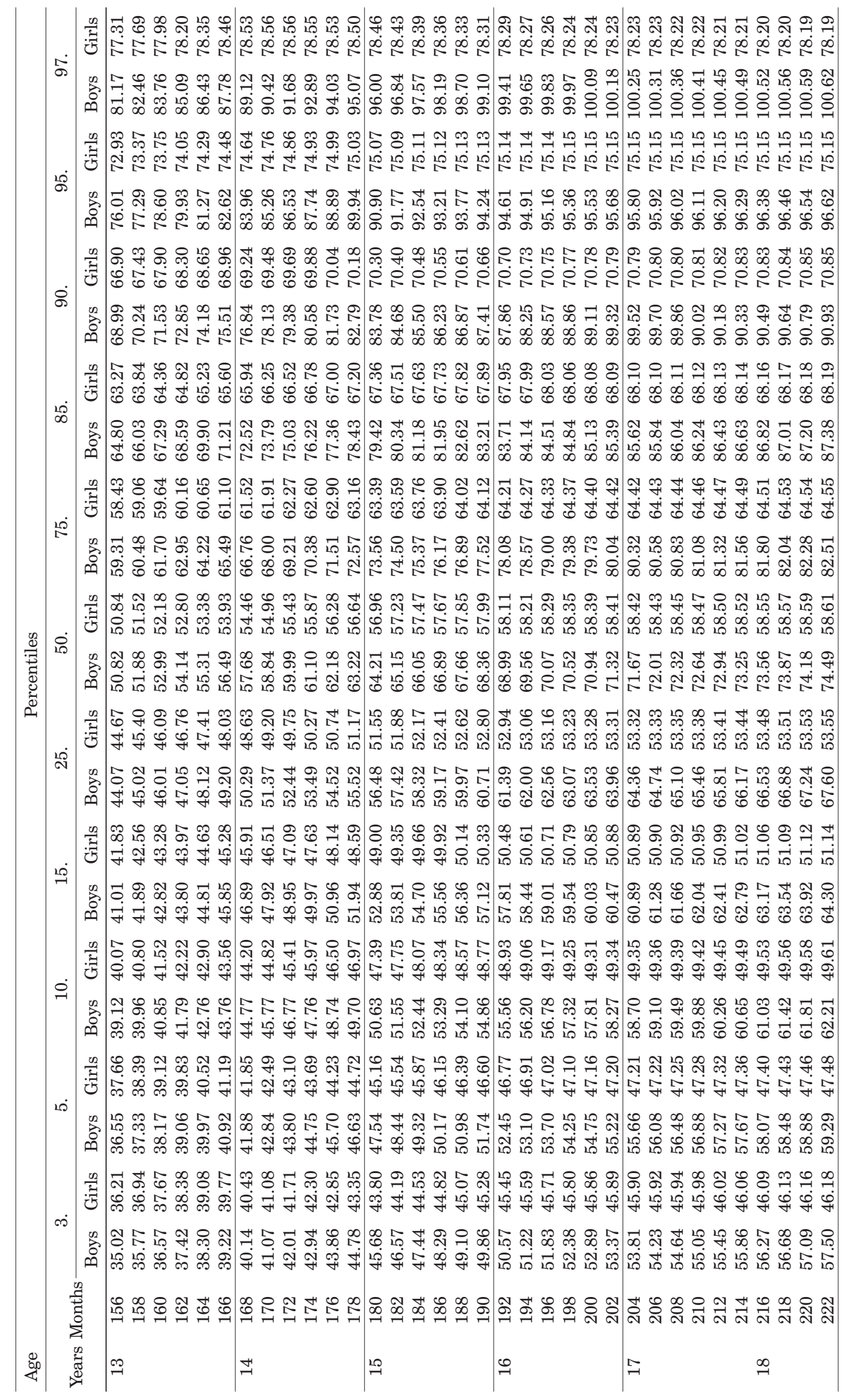


than $1991^{20}$. Secular trends, with different intensity, is present in other European countries. In Poland comparative study of various measurements from 1880-2000 of children aged 3-18 years shows that boys in twentieth century are $17 \mathrm{~cm}$ taller and $11 \mathrm{~kg}$ heavier, girls are 13 $\mathrm{cm}$ taller and $13 \mathrm{~kg}$ heavier ${ }^{7}$. In Denmark between 19641993 in children aged 6-20 there is increase of heights of approximately $3 \mathrm{~cm}$ for both sexes ${ }^{12}$. In Ireland between 1990-2005 children aged 8-12, 8 years old boys are 4.2 $\mathrm{cm}$ and girls $0.4 \mathrm{~cm}$ taller. Boys are $1.1 \mathrm{~kg}$ lighter and girls $1.1 \mathrm{~kg}$ heavier ${ }^{2}$. In Flanders, Belgium since 1969 there is increase in adult groups for height $1.2 \mathrm{~cm}$ in boys and $0.8 \mathrm{~cm}$ in girls, boys are $0.9 \mathrm{~kg}$ heavier and girls are $1.0 \mathrm{~kg}$ heavier ${ }^{5}$. In Sweden comparison of generations born 1955-1958 wit those born 1973-1975 shows that 19 year old boys are $1.9 \mathrm{~cm}$ taller and $5.7 \mathrm{~kg}$ heavier, girls are $2.3 \mathrm{~cm}$ taller and $3.4 \mathrm{~kg}$ heavier ${ }^{6}$. In Norway comparison between 1970-1980 period with 2003-2006 period for children aged 4-17 years shows increase weight-for-height for the upper percentile ${ }^{8}$. In Turkey 1993-2003 study showed 1.7-5.5 cm increase of height and 2.7-6.3 $\mathrm{kg}$ increase in weight ${ }^{4}$. In Italy comparison between 1974-1975 and 2001-2002 of 6 years age group shows 1.8 $\mathrm{kg}$ increase of height and $5.0 \mathrm{~kg}$ increase in 9 years age $\operatorname{group}^{10}$.

\section{R E F E R E N C E S}

1. GELANDER L, Acta Paediatr, 95 (2006) 517. — 2. O’NEILL JL, MCCARTHY SN, BURKE SJ, HANNON EM, KIELY M, FLYNN A, FLYNN MA, GIBNEY MJ, Eur J Clin Nutr, 61 (2007) 743. - 3. ÖZER BK, Econ Hum Biol, 5 (2007) 280. - 4. SIMSEK F, ULUKOL B, GULNAR SB, Child Care Health Dev, 31 (2005) 441. - 5. ROELANTS M, HAUSPIE R, HOPPENBROUWERS K, Ann Hum Biol, 36 (2009) 680. 6. WIKLAND KA, LUO ZC, NIKLASSON A, KARLBERG J, Acta Paediatr, 91 (2002) 739. - 7. KRAWCZYNSKI M, WALKOWIAK J, KRZYZANIAK A, Acta Paediatr, 92 (2003) 277. - 8. JÚLÍUSSON PB, ROELANTS M, EIDE GE, MOSTER D, JUUL A, HAUSPIE R, WAALER PE, BJERKNES R, Tidsskr Nor Laegeforen, 129 (2009) 281. - 9. BODSZAR EB, ZSAKAI A, Coll Antropol, 26 (2002) 477. - 10. TOSELLI S, VENTRELLA AR, FRANZAROLI G, BRASILI P, Coll Antropol 30 (2006) 65 - 11. WERNER B, BODIN L, J Adolesc Health, 41 (2007) 536. - 12 JUUL A, TEILMANN G, SCHEIKE T, HERTEL NT, HOLM K, LAUR-

V. Jureša

University of Zagreb, School of Medicine, »Andrija Štampar « School of Public Health, Rockefeller Street 4, 10000 Zagreb, Croatia

e-mail:vjuresa@snz.hr

\section{KRIVULJE RASTA ŠKOLSKE DJECE U HRVATSKOJ I SEKULARNI TRENDOVI U POSLJEDNJIH DVADESET GODINA}

\section{S A Ž E T A K}

Cilj istraživanja je izrada novih krivulja rasta za Hrvatsku s referentnim vrijednostima za visinu i masu za dječake i djevojčice u dobi od 6,5 do 18,5 godina. Analizirane su razlike rezultata mjerenja prethodnih i ovog istraživanja te procijenjen sekularni trend rasta. Istraživanje se temelji na višestupanjskom stratificiranom uzorku školske djece $u$
In conclusion registered switch in percentile curves values for body height in our study in comparison with Prebeg's study twenty-two years ago shows importance of renewing of percentile curves in same population regarding presence of secular trend because previously used growth charts in Croatia are obsolete. Second important reason for repeated measurements is use of percentile curves in evaluation of children's growth and development, relevant criteria must exist. If today's children with risk for decreased growth would be assessed with old percentile curves large number of children would not been detected. It emphasizes need for continuous renewal of growth charts. Data collected from school health records, especially in Croatia with existing School health service and their preventive activities in every school and university in Republic of Croatia, may be excellent resource.

\section{Acknowledgements}

The study was supported by the Ministry of Science, Education and Sports Republic of Croatia, project number 108-1080135-0263.
SEN EM, MAIN KM, SKAKKEBAEK NE, Int J Androl, 29 (2006) 247. 13. PREBEG Ž, Liječ Vjesn, 124 (2002) 3 - 14. CANADIAN SOCIETY FOR INTERNATIONAL HEALTH, 2003 Croatian Adult Health Survey Users guide (Canadian Society for International Health, 2003). - 15. ( Health and Central Bureau of Statistics: a joint effort in implementing can Statistical Association Meeting, Survey Research Methods, Toronto, Canada: American Statistical Association 2004 - 16. COLE TJ, GREEN PJ, Stat Med, 11 (1992) 1305. - 17. COLE TJ, FREEMAN JV, PREECE MA, Stat Med, 17 (1998) 407. - 18. COLE TJ, Proc Nutr Soc, 59 (2000) - 19. PREBEG Z, JURESA V, KUJUNDZIC M, Ann Hum Biol, 22 (1995) 99. - 20. BRALIĆ I, TAHIROVIĆ H, MATANIĆ, Eur J Pediatr, (2011) Apr 16;DOI 10.1007/s00431-011-1470-1. 
Hrvatskoj u dobi od 6,5 do 18,5 godina. Istraživanje je provedeno na 11702 djece (6046 dječaka i 5656 djevojčica), obuhvaćeno je 94,5\% planirane populacije. Izrađene su krivulje rasta za tjelesnu visinu i masu korištenjem LMS metode. Dobiveni rezultati pokazuju porast tjelesne visine i mase u posljednjih 20 godina. Sedmogodišnji dječaci u našem istraživanju su $2,7 \mathrm{~cm}$ i djevojčice $2,5 \mathrm{~cm}$, a osamnaestogodišnji dječaci su $2,9 \mathrm{~cm}$ i djevojčice $1,8 \mathrm{~cm}$ viši od vršnjaka prije 20 godina. Najveći porast tjelesne visine je $6,5 \mathrm{~cm}$ u dječaka u dobi 13-14 godina i u djevojčica od 12 godina $5,0 \mathrm{~cm}$. Sedmogodišnjaci su $2,4 \mathrm{~kg}$ i djevojčice $2,5 \mathrm{~kg}$ teži od vršnjaka prije 20 godina, a osamnaestogodišnjaci su teži $6,0 \mathrm{~kg}$ i djevojke 0,5 kg. Najveći porast tjelesne mase zabilježen je u šesnaest godišnjih dječaka $8,7 \mathrm{~kg}$ i u djevojčica dobi 11-12 godina $5,2 \mathrm{~kg}$. Sve vrijednosti centile za tjelesnu visinu i masu su više u odnosu na prijašnje istraživanje (naša 3 centila odgovara prijašnjoj 10, naša 10 prijašnjoj 25, itd.). U zaključku, promjena vrijednosti centilnih krivulja za tjelesnu visinu i masu u odnosu na ranije istraživanje pokazuje važnost izrade novih referentnih krivulja rasta za navedenu populaciju jer zbog sekularnog trenda stare krivulje ne bi bilo primjereno više koristiti. 